\title{
SENSITIVITAS ETIS DAN PERTIMBANGAN MORAL MAHASISWA AKUNTANSI TERHADAP DILEMA BISNIS
}

\section{ETHICAL SENSITIVITY AND MORAL CONSIDERATIONS OF ACCOUNTING STUDENTS TOWARD BUSINESS DILEMMA.}

\author{
Kiki Apriyana ${ }^{1}$ ), Lisa Martiah Nila Puspita² \\ Universitas Bengkulu, Jl. WR. Supratman,Kandang Limun, Muara Bangkahulu, Bengkulu $\left.{ }^{1}\right)^{2}$ ) \\ kiky_apriyana04@yahoo.com ${ }^{1}$ ) lisa_mnp@unib.ac.id ${ }^{2}$ )
}

\begin{abstract}
ABSTARACT
The purpose of this study was to prove the influence of the dimension of moral intensity (perceived overall harm and perceived societal pressure) to the ethical sensitivity and moral judgments of accounting students and to prove the influence of the dimension of moral intensity to the moral judgments through ethical sensitivity. This study used four case scenarios to explain the impact of the dimension of moral intensity, such as passing of company policies, approving of a questionable expense report, manipulating of company books, and extending of questionable credit, by using 85 samples of accounting students in University of Bengkulu. Primary data were obtained from the result of the dissemination of the questionnaires. The testing of hypotesis in this study was using multiple regression analysis and hierarchical regression analysis. The result showed that perceived overall harm has negative influence to the ethical sensitivity and moral judgements of accounting students, meanwhile perceived societal pressure has positive influence to the ethical sensitivity and moral judgments of accounting students. The result also showed that the perceived overall harm and perceived societal pressure influence moral judgements of accounting students through ethical sensitivity.
\end{abstract}

Key words: Ethical Sensitivity, Moral Judgments, Moral Intensity, Perceived Overall Harm, and Perceived Societal Pressure.

\section{ABSTRAK}

Tujuan dari penelitian ini adalah untuk membuktikan pengaruh dimensi intensitas moral (persepsi kerugian keseluruhan dan tekanan sosial yang dirasakan) terhadap sensitivitas etika dan penilaian moral mahasiswa akuntansi dan untuk membuktikan pengaruh dimensi intensitas moral terhadap penilaian moral. melalui sensitivitas etika. Penelitian ini menggunakan empat skenario kasus untuk menjelaskan dampak dari dimensi intensitas moral, seperti pengesahan kebijakan perusahaan, menyetujui laporan pengeluaran yang dipertanyakan, memanipulasi buku perusahaan, dan memperluas kredit yang dipertanyakan, dengan menggunakan 85 sampel mahasiswa akuntansi di Universitas Bengkulu. Data primer diperoleh dari hasil penyebaran kuesioner. Pengujian hipotesis dalam penelitian ini menggunakan analisis regresi berganda dan analisis regresi hirarkis. Hasil penelitian menunjukkan bahwa kerugian keseluruhan yang dirasakan memiliki pengaruh negatif terhadap sensitivitas etika dan penilaian moral mahasiswa akuntansi, sementara itu tekanan sosial yang dirasakan memiliki pengaruh positif terhadap sensitivitas etika dan penilaian moral mahasiswa akuntansi. Hasilnya juga menunjukkan bahwa kerugian keseluruhan yang dirasakan dan tekanan sosial yang dirasakan mempengaruhi penilaian moral mahasiswa akuntansi melalui sensitivitas etis.

Kata kunci: Sensitivitas Etis, Pertimbangan Moral, Intensitas Moral, Persepsi Keseluruhan Bahaya, dan Tekanan Sosial Persepsi.

\section{PENDAHULUAN}

Keberadaan Kode Etik akuntan dimaksudkan untuk mengatur perilaku akuntan dalam menjalankan pekerjaannya. Namun, dalam menjalankan pekerjaannya, akuntan publik banyak dihadapkan pada sebuah dilema etika dalam pengambilan keputusan yang etis dan tidak etis. Dilema etika merupakan situasi dimana seorang akuntan harus membuat keputusan tentang perilaku seperti apa yang tepat untuk dilakukannya (Arens et al., 2011). Dilema ini 
mengakibatkan seorang akuntan publik berada pada konflik audit dalam proses auditya. Konflik dalam audit akan berkembang pada saat auditor mengungkapkan informasi yang oleh klien tidak ingin dipublikasikan kepada umum (Lubis, 2010).

Banyaknya kasus pelanggaran etika yang terjadi, telah menurunkan kepercayaan masyarakat terhadap profesionalisme seorang akuntan publik. Hal ini menunjukkan perlunya upaya untuk mengembalikan kepercayaan masyarakat terhadap profesi akuntan. Hal ini tidak terlepas dari dunia pendidikan dimana calon akuntan mengenal dan mempelajari tentang ilmu akuntansi. Dunia pendidikan yang baik akan membentuk mahasiswa menjadi calon akuntan yang mempunyai sikap profesional dan berlandaskan pada standar moral dan etika (Rianto, 2008 dalam Juita, 2011).

Penelitian ini merupakan replikasi dari penelitian yang telah dilakukan oleh Shawver \& Shawver (2013) dengan menggunakan dua dari Model Empat Komponen Rest (1986) yaitu sensitivitas etis dan pertimbangan moral, serta model intensitas moral Jones (1991) yang dikelompokkan menjadi dua dimensi yaitu perceived overall harm dan perceived societal pressure. dikelompokkan menjadi dua dimensi yaitu perceived overall harm dan perceived societal pressure. Penelitian ini dilakukan kembali dengan maksud apakah hasil yang diperoleh akan sama dengan penelitian sebelumnya dengan menggunakan teori yang sama. Selain itu penelitian mengenai pengaruh komponen intensitas moral terhadap proses pengambilan keputusan masih sedikit dilakukan.

Berdasarkan latar belakang di atas maka permasalahan dalam penelitian ini adalah apakah perceived overall ham dan perceived societal pressure berpengaruh terhadap kemampuan seorang mahasiswa akuntansi dalam mengidentifikasi masalah etika, membuat pertimbangan moral yang bertentangan dengan tindakan, dan membuat pertimbangan moral yang bertentangan dengan tindakan melalui sensitivitas etis. Sesuai dengan permasalahan yang dikemukakan maka tujuan penelitian ini adalah untuk membuktikan apakah perceived overall harm dan perceived societal pressure berpengaruh terhadap kemampuan seorang mahasiswa akuntansi dalam mengidentifikasi masalah etika, membuat pertimbangan moral yang bertentangan dengan tindakan, dan membuat pertimbangan moral dengan tindakan melalui sensitivitas etis.

\section{KERANGKA TEORITIS DAN HIPOTESIS}

\section{Teori Etika}

Menurut Kanter (2001) dalam bukunya Agoes dan Ardana (2014), bahwa etika berasal dari bahasa Yunani yaitu ethos yang merupakan bentuk tunggal, yang memiliki arti tempat tinggal, padang rumput, kandang, kebiasaan, adat, watak, perasaan, sikap, dan cara berpikir. Beberapa teori etika yang berkembang dalam rangka pengembangan ilmu pengetahuan yaitu: egoisme, utilitiarianisme, dan deontologi. Teori etika dapat membantu proses pengambilan keputusan yang berkaitan dengan moral dan justifikasi terhadap keputusan tersebut. Dengan adanya teori etika kasus-kasus yang terjadi di Indonesia diharapkan dapat berkurang di masa yang akan datang (Bertens, 2007).

\section{Dilema Etika dan Keputusan Etis}

Dilema etika merupakan situasi dimana seseorang harus membuat keputusan tentang perilaku seperti apa yang tepat untuk dilakukan (Arens et al., 2011. Sebuah model pengambilan keputusan etis tidak berada kepada pemahaman bagaimana seharusnya seseorang membuat keputusan etis (ought to do), namun lebih kepada pengertian bagaimana proses pengambilan keputusan etis itu sendiri. Alasannya adalah sebuah pengambilan keputusan etis akan 
memungkinkan menghasilkan keputusan yang etis dan keputusan yang tidak etis, dan memberikan label atau mendefinisikan apakah suatu keputusan tersebut etis atau tidak etis akan mungkin sangat menyesatkan (Novius \& Sabeni 2008).

\section{Model Empat Komponen Rest}

Rest (1986) dalam Shawver \& Shawver (2013) menyatakan bahwa terdapat empat langkah dalam proses pengambilan keputusan etis yang mencakup sensitivitas etis/moral, pertimbangan moral, niat moral, dan perilaku moral. Proses pengambilan keputusan dengan model Rest (1986) dapat digambarkan sebagai berikut:

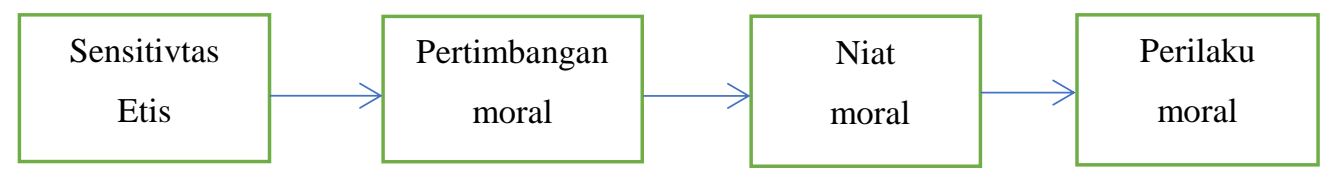

Gambar 1. Proses Pengambilan Keputusan Rest

\section{Sensitivitas Etis}

Sensitivitas merupakan tahap pertama dalam proses pengambilan keputusan etis menurut Rest (1986). Sensitivitas etis merupakan kemampuan seseorang dalam mengidentifikasi masalah etis ketika dihadapkan pada situasi yang mengandung dilema etis. Shaub et al. (1993), mendefinisikan sensitivitas etis sebagai kemampuan dalam mengambil suatu keputusan dengan mempertimbangkan sifat dasar etis dari keputusan yang dibuat. Kemampuan tersebut sangat penting bagi akuntan ketika harus menghadapi dilema etika. Hunt dan Vitell (1986) menyatakan bahwa pemahaman seseorang mengenai masalah etis dipengaruhi oleh pengalaman dan lingkungan.

\section{Pertimbangan Moral}

Pertimbangan moral terjadi ketika seseorang mengevaluasi mengenai tindakan seperti apa yang benar secara moral. Pertimbangan moral adalah tahap kedua dari model Rest (1986). Pertimbangan moral menggambarkan kemampuan untuk mengenali hal yang benar secara moral yang harus dilakukan. Jones (1991) berpendapat bahwa pemikiran moral memerlukan waktu dan energi menyangkut pengumpulan fakta, mempertimbangkan prinsip-prinsip dan nilai, serta pembuatan keputusan.

\section{Intensitas Moral dan Komponen Intensitas Moral}

Menurut Jones (1991) dalam Novius (2008), intensitas moral adalah sebuah konstruk yang mencakup karakteristik-karakteristik yang merupakan perluasan dari isu-isu yang terkait dengan isu moral utama dalam sebuah situasi yang akan mempengaruhi persepsi individu mengenai masalah etika dan intensi keperilakuan yang dimilikinya.

\section{Intensitas Moral dan Model Empat Komponen Rest}

Proses pengambilan keputusan sering kali digerakkan oleh adanya masalah moral yang membutuhkan sebuah solusi atau respon dan juga beberapa tindakan (Jones, 1991). Jones (1991) mengatakan bahwa intensitas moral yang akan langsung mempengaruhi setiap tahap dalam kerangka pengambilan keputusan etis. Intensitas moral akan mempengaruhi pengenalan individu terhadap isu moral melalui pengenalan individu terhadap dampak dari keputusan moral. Intensitas moral juga akan mempengaruhi pertimbangan moral seseorang setelah 
mengetahui dampak dari keputusan moral. Intensitas moral juga memainkan peranan penting dalam membangun niat moral dengan mempengaruhi niat moral melalui emosi, perasaan, dan suasana hati $(\mathrm{mood})$, yang nantinya akan terwujud dalam perilaku moral.

\section{Intensitas Moral dan Senisitivitas Etis}

Penelitian sebelumnya juga menunjukkan bahwa perceived overall harm dan perceived societal pressure mempengaruhi sensitivitas etis mahasiswa akuntansi (Sweeney \& Costello, 2009; Yang \& Wu, 2009), profesional pemasaran (Shinghapakdi et al., 1996). Begitu juga penelitian yang dilakukan Shawver \& Shawver (2013) menunjukkan bahwa dimensi intensitas moral mempengaruhi evaluasi etis mahasiswa akuntansi. Berdasarkan penjelasan dan penelitian terdahulu di atas bahwa dimensi overall harm dan societal pressure dapat mempengaruhi sensitivitas mahasiswa akuntansi, maka hipotesis dalam penelitian ini yaitu:

H1a: Perceived overall harm berpengaruh terhadap kemampuan seorang mahasiswa akuntansi dalam mengidentifikasi masalah etika.

H1b: Perceived societal pressure terhadap suatu tindakan yang merugikan, berpengaruh terhadap kemampuan seorang mahasiswa akuntansi dalam mengidentifikasi masalah etika.

\section{Intensitas Moral dan Pertimbangan Moral}

Beberapa penelitian sebelumnya telah meneliti pengaruh dimensi intensitas moral terhadap pertimbangan moral dan hasilnya menunjukkan bahwa perceived overall harm dan perceived societal pressure mempengaruhi pertimbangan moral mahasiswa akuntansi (Sweeney \& Costello, 2009; Yang \& Wu, 2009), profesional pemasaran (Shinghapakdi et al., 1996). Begitu juga penelitian yang dilakukan Shawver \& Shawver (2013) menunjukkan bahwa dimensi intensitas moral mempengaruhi penilaian etis mahasiswa akuntansi. Berdasarkan penjelasan dan penelitian terdahulu di atas bahwa dimensi overall harm dan societal pressure dapat mempengaruhi penilaian moral mahasiswa akuntansi, maka hipotesis yang akan diuji yaitu:

H2a: Perceived overall harm berpengaruh terhadap kemampuan seorang mahasiswa akuntansi dalam membuat pertimbangan moral yang bertentangan dengan tindakan.

H2b: Perceived societal pressure berpengaruh terhadap kemampuan seorang mahasiswa akuntansi dalam membuat pertimbangan moral yang bertentangan dengan tindakan.

\section{Intensitas Moral dan Pertimbangan Moral melalui Sensitivitas Etis}

Jones (1991) mengatakan bahwa intensitas moral yang akan langsung mempengaruhi setiap tahap kerangka pengambilan keputasan etisnya. Hal ini sejalan dengan hasil penelitian sebelumnya yang menunjukkan bahwa masing-masing dimensi intensitas moral secara signifikan berkorelasi langsung dengan penilaian etis (Sighapakdi et al., (1996); Sweeney \& Costello (2009); Yang \& Wu (2009) dan Shawver \& Shawver (2013)). Maka hipotesis dalam penelitian ini adalah:

H3a : Perceived overall harm bepengaruh terhadap kemampuan seorang mahasiswa akuntansi dalam membuat pertimbangan moral yang bertentangan dengan tindakan melalui sensitivitas etis.

$\mathrm{H} 3 \mathrm{~b}$ : Perceived societal pressure berpengaruh terhadap kemampuan seorang mahasiswa akuntansi dalam membuat pertimbangan moral yang bertentangan dengan tindakan melalui sensitivitas etis. 


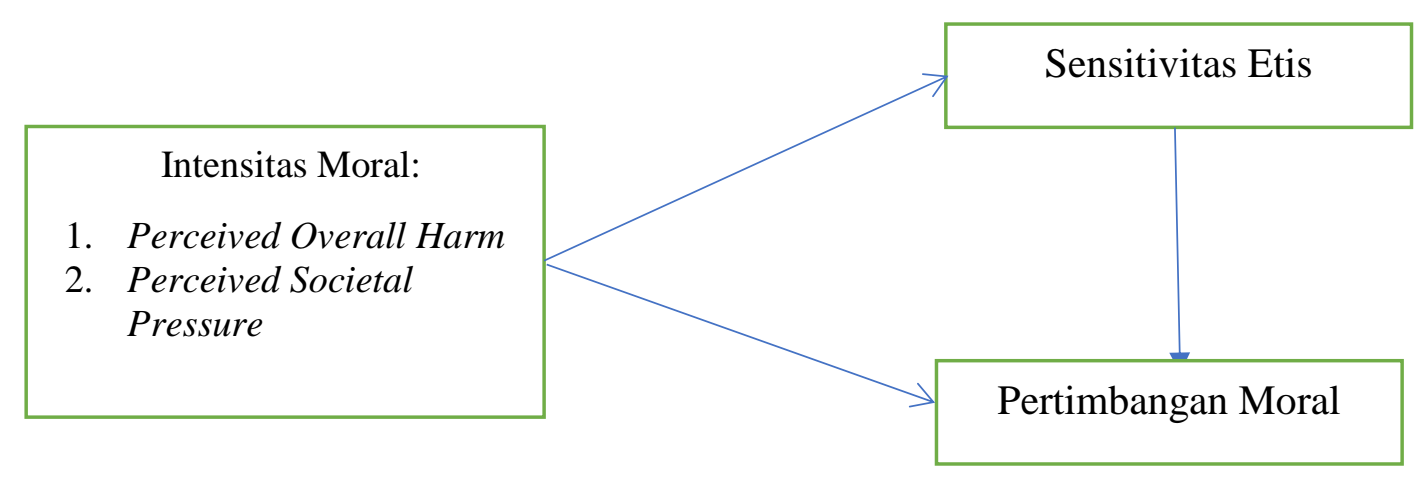

Gambar2. Kerangka Pemikiran

METODE PENELITIAN

\section{Metode Pengambilan Sampel}

Jenis penelitian yang digunakan dalam penelitian ini adalah penelitian kuantitatif dengan metode survey. Data dalam penelitian ini adalah data primer dengan menggunakan kuesioner yang terdiri dari empat skenario kasus yang diambil dari Arens et al., (2011) yaitu melanggar kebijakan perusahaan dan kasus yang diambil dari Novius (2008) yang sebelumnya juga telah digunakan oleh Sweeney \& Costello (2009) dan Yang \& Wu (2009) yaitu menyetujui laporan biaya yang diragukan, memanipulasi pembukuan perusahaan dan menambah kredit yang diragukan.

Sampel yang digunakan dalam penelitian ini adalah mahasiswa S1 Akuntansi reguler angkatan 2013 Universitas Bengkulu berjumlah 117 mahasiswa. Data dalam penelitian ini dianalisis dengan menggunakan alat analisis statistika dengan menggunakan program SPSS 17.0 for windows. Sebelum pengujian hipotesis dilakukan, pengujian statistik deskriptif, validitas, reliabilitas, dan normalitas data dilakukan terlebih dahulu. Pengujian hipotesis dilakukan dengan menggunakan analisis mulitple regression dan hierarchical regression. Pada penlitian ini untuk menguji hipotesis dengan variabel intervening mengguakan analisis jalur (Ghozali, 2013). Ada atau tidaknya pengaruh intervening dilihat dengan membandingkan nilai koefisien beta dengan menghitung pengaruh langsung dan tidak langsung. Jika pengaruh tidak langsung lebih besar dari pengaruh langsung, maka terdapat pengaruh intervening (mediasi).

\section{HASIL PENELITIAN DAN PEMBAHASAN}

\section{Statistik Deskriptif}

\begin{tabular}{|c|c|c|c|c|c|c|c|c|c|c|c|c|c|c|c|}
\hline \multirow{2}{*}{$\begin{array}{l}\text { Variabel } \\
\text { Penelitian }\end{array}$} & \multirow[t]{2}{*}{$\mathrm{n}$} & \multirow{2}{*}{$\begin{array}{l}\text { Kisaran } \\
\text { Teoritis }\end{array}$} & \multirow{2}{*}{$\begin{array}{l}\text { Mean } \\
\text { Teoritis }\end{array}$} & \multicolumn{3}{|c|}{ Kasus 1} & \multicolumn{3}{|c|}{ Kasus 2} & \multicolumn{3}{|c|}{ Kasus 3} & \multicolumn{3}{|c|}{ Kasus 4} \\
\hline & & & & $\begin{array}{c}\text { Kisaran } \\
\text { Aktual }\end{array}$ & Mean & $S D$ & $\begin{array}{c}\text { Kisaran } \\
\text { Aktual }\end{array}$ & Mean & $S D$ & $\begin{array}{c}\text { Kisaran } \\
\text { Aktual }\end{array}$ & Mean & $S D$ & $\begin{array}{c}\text { Kisaran } \\
\text { Aktual }\end{array}$ & Mean & $S D$ \\
\hline Sensitivitas etis & 85 & $1-7$ & 4 & $1-7$ & 2,44 & 1,58 & $1-7$ & 2,01 & 1,48 & $1-7$ & 1,92 & 1,40 & $1-7$ & 2,36 & 1,69 \\
\hline $\begin{array}{l}\text { Pertimbangan } \\
\text { Moral }\end{array}$ & 85 & $1-7$ & 4 & $1-7$ & 2,86 & 1,42 & $1-7$ & 2,40 & 1,48 & $1-7$ & 2,24 & 1,43 & $1-7$ & 3,04 & 1,91 \\
\hline $\begin{array}{l}\text { Percived } \\
\text { Overall Harm }\end{array}$ & 85 & $4-28$ & 16 & $5-28$ & 17,04 & 4,72 & $7-28$ & 18,60 & 5,43 & $4-28$ & 18,34 & 5,24 & 4-28 & 17,28 & 4,91 \\
\hline \begin{tabular}{|l} 
Besarnya \\
Konsekuensi
\end{tabular} & 85 & $1-7$ & 4 & $1-7$ & 4,31 & 1,48 & $1-7$ & 4,88 & 1,55 & $1-7$ & 4,74 & 1,68 & $1-7$ & 4,51 & 1,58 \\
\hline $\begin{array}{l}\text { Probabilitas } \\
\text { Efek }\end{array}$ & 85 & $1-7$ & 4 & $1-7$ & 4,49 & 1,46 & $1-7$ & 5,00 & 1,53 & $1-7$ & 4,93 & 1,46 & $1-7$ & 4,65 & 1,45 \\
\hline
\end{tabular}


SENSITIVITAS ETIS DAN PERTIMBANGAN MORAL...

Kiki Apriyana dan Lisa Martiah Nila Puspita

\begin{tabular}{|c|c|c|c|c|c|c|c|c|c|c|c|c|c|c|c|}
\hline \multirow{2}{*}{$\begin{array}{l}\text { Variabel } \\
\text { Penelitian }\end{array}$} & \multirow[t]{2}{*}{$\mathrm{n}$} & \multirow{2}{*}{$\begin{array}{l}\text { Kisaran } \\
\text { Teoritis }\end{array}$} & \multirow{2}{*}{$\begin{array}{l}\text { Mean } \\
\text { Teoritis }\end{array}$} & \multicolumn{3}{|c|}{ Kasus 1} & \multicolumn{3}{|c|}{ Kasus 2} & \multicolumn{3}{|c|}{ Kasus 3} & \multicolumn{3}{|c|}{ Kasus 4} \\
\hline & & & & $\begin{array}{c}\text { Kisaran } \\
\text { Aktual }\end{array}$ & Mean & $S D$ & $\begin{array}{c}\text { Kisaran } \\
\text { Aktual }\end{array}$ & Mean & $S D$ & $\begin{array}{c}\text { Kisaran } \\
\text { Aktual }\end{array}$ & Mean & $S D$ & $\begin{array}{c}\text { Kisaran } \\
\text { Aktual }\end{array}$ & Mean & $S D$ \\
\hline $\begin{array}{l}\text { Kedekatan } \\
\text { Temporal }\end{array}$ & 85 & $1-7$ & 4 & $1-7$ & 4,01 & 1,49 & $1-7$ & 4,40 & 1,67 & $1-7$ & 4,08 & 1,63 & $1-7$ & 3,99 & 1,62 \\
\hline $\begin{array}{l}\text { Konsentrasi } \\
\text { Efek }\end{array}$ & 85 & $1-7$ & 4 & $1-7$ & 4,22 & 1,57 & $1-7$ & 4,32 & 1,87 & $1-7$ & 4,59 & 1,66 & $1-7$ & 4,13 & 1,68 \\
\hline $\begin{array}{l}\text { Perceived } \\
\text { Societal } \\
\text { Pressure } \\
\end{array}$ & 85 & $2-14$ & 8 & $2-14$ & 6,11 & 2,56 & $2-14$ & 5,29 & 2,67 & $2-14$ & 5,74 & 2,97 & $2-14$ & 6,02 & 2,92 \\
\hline Kedekatan & 85 & $1-7$ & 4 & $1-7$ & 3,34 & 1,66 & $1-7$ & 2,76 & 1,65 & $1-7$ & 3,05 & 1,72 & $1-7$ & 3,15 & 1,74 \\
\hline $\begin{array}{l}\text { Konsensus } \\
\text { Sosial }\end{array}$ & 85 & $1-7$ & 4 & $1-7$ & 2,76 & 1,40 & $1-7$ & 2,53 & 1,52 & $1-7$ & 2,70 & 1,75 & $1-7$ & 2,87 & 1,65 \\
\hline $\begin{array}{l}\text { Intensitas } \\
\text { Moral }\end{array}$ & 85 & $6-42$ & 24 & $7-42$ & 23,14 & 5,92 & $11-36$ & 23,89 & 6,33 & $6-36$ & 24,08 & 6,70 & $6-40$ & 23,29 & 6,35 \\
\hline
\end{tabular}

\section{Uji Kualitas Data}

\section{Uji Validitas}

Validitas digunakan untuk mengukur apakah pernyataan pada kuesioner mampu mengungkapkan sesuatu yang diukur oleh kuesioner. Pengujian validitas dalam penelitian ini dilakukan dengan penggunaan Confirmatory Factor Analisys(CFA). Valid atau tidaknya pernyataan dalam kuesioner diukur dengan melihat nilai KMO MSA dan Bartlett's test. Jika KMO MSA >0,5 maka pernyataan kuesioner dinyatakan valid. Hasil pengujian validitas dalam penelitian ini dapat dilihat pada tabel di bawah ini:

Tabel

\section{Hasil Pengujian Validitas}

\begin{tabular}{c|c|c}
\hline Variabel & KMO \& Bartllet' test & Keterangan \\
\hline Kasus 1 & 0,748 (Sig. 0,000) & Valid \\
\hline Kasus 2 & 0,744 (Sig. 0,000) & Valid \\
\hline Kasus 3 & 0,736 (Sig. 0,000) & Valid \\
\hline Kasus 4 & 0,710 (Sig. 0,000) & Valid \\
\hline
\end{tabular}

Sumber: data primer diolah, 2017

\section{Uji Reliabilitas}

Reliabilitas digunakan untuk mengukur apakah jawaban responden terhadap pernyataan dalam kuesioner konsisten atau stabil dari waktu ke waktu. Uji reliabilitas pada penelitian ini dilakukan dengan menggunakan uji statistic Croncbach's Alpha. Kuesioner dikatakan reliabel, jika nilai Cronbach's Alpha lebih besar dari 0,70 (Ghozali, 2013). Hasil pengujian reliabilitas pada penelitian ini dapat dilihat pada tabel di bawah ini: 
Tabel

Hasil Pengujian Reliabilitas

\begin{tabular}{|c|c|c|c|c|c|}
\hline \multirow[t]{2}{*}{ Variabel } & \multicolumn{4}{|c|}{ Cronbach' Alpha } & \multirow[t]{2}{*}{ keterangan } \\
\hline & Kasus 1 & Kasus 2 & Kasus 3 & Kasus 4 & \\
\hline Besarnya konsekuensi & \multirow{6}{*}{$\mathbf{0 , 7 3 1}$} & \multirow{6}{*}{0,719} & \multirow{6}{*}{0,761} & \multirow{6}{*}{$\mathbf{0 , 7 3 2}$} & \multirow{6}{*}{ Reliabel } \\
\hline Consensus social & & & & & \\
\hline Probabilitas efek & & & & & \\
\hline Kedekatan temporal & & & & & \\
\hline Kedekatan & & & & & \\
\hline Konsentrasi efek & & & & & \\
\hline
\end{tabular}

Sumber: data primer diolah, 2017

Berdasarkan tabel pengujian reliabilitas tabel 4.4 di atas, dapat dilihat bahwa seluruh variabel yang digunakan dalam penelitian memiliki nilai Cronbach's Alpha lebih besar dari 0,70, sehingga dapat disimpulkan bahwa item pernyataan dalam penelitian adalah reliabel.

\section{Uji Asumsi Klasik}

\section{Uji Normalitas}

Uji normalitas pada penelitian ini menggunakan uji statistik One Sample KolmogorovSmirnov Test. Data dikatakan normal apabila Asymp.sig (2-tailed) lebih besar dari 0,05 (Ghozali, 2013). Hasil pengujian normalitas pada penelitian dapat dilihat pada tabel 4.5 di bawah ini:

Tabel

Hasil Pengujian Normalitas

\begin{tabular}{l|c|c|c}
\hline \multicolumn{1}{c|}{ Variabel } & $\begin{array}{c}\text { Kolmogorov- } \\
\text { Smirnov-Test }\end{array}$ & Asymp.sig (2-tailed) & Keterangan \\
\hline Kasus 1 & 0,799 & 0,546 & Normal \\
\hline Kasus 2 & 0,749 & 0,628 & Normal \\
\hline Kasus 3 & 0,656 & 0,783 & Normal \\
\hline Kasus 4 & 1,080 & 0,194 & Normal \\
\hline \multicolumn{2}{c}{ Sumber: data primer diolah, 2017 }
\end{tabular}

Sumber: data primer diolah, 2017

Berdasarkan tabel di atas terlihat bahwa hasil pengujian normalitas data menunjukkan nilai Asymp.sig (2-tailed) lebih besar dari 0,05 untuk semua variabel pada setiap kasus. Dengan demikan dapat disimpulkan bahwa data yang digunakan dalam penelitian ini berdistribusi normal.

\section{Pembahasan}

\section{Pengaruh Intensitas Moral terhadap Sensitivitas Etis Mahasiswa Akuntansi Hipotesis 1a (H1a)}

Berdasarkan hasil pengujian hipotesis, hipotesis 1a (H1a) membuktikan bahwa perceived overallharm berpengaruh negatif terhadap kemampuan seorang mahasiswa akuntansi dalam mengidentifikasi masalah etika. Berdasarkan hasil tersebut maka hipotesis 1a (H1a) diterima. Hasil ini menunjukkan bahwa semakin tinggi perceived overall harm (kerugian) yang ditimbulkan atas suatu tindakan tidak etis, maka semakin rendah kemampuan mahasiswa akuntansi dalam mengidentifikasi masalah etika (sensitivitas etis rendah) atau 
sebaliknya semakin tinggi kemampuan mahasiswa akuntansi dalam mengidentifikasi masalah etika, maka semakin rendah perceived overall harm (kerugian) yang ditimbulkan atas suatu tindakan tidak etis.

Perceived overall harm menunjukkan persepsi seseorang mengenai tingkat kerugian atau manfaat yang ditimbulkan sebagai konsekuensi dari suatu tindakan moral. Pada penelitian ini, hasil menunjukkan bahwa perceived overall harm berpengaruh negatif hanya pada kasus 3 yaitu memanipulasi pembukuan perusahaan. Artinya, mahasiswa akuntansi tahu bahwa memanipulasi pembukuan perusahaan merupakan suatu tindakan yang akan mengakibatkan kerugian yang besar yang mungkin akan terjadi dalam waktu dekat. Namun, tingkat kerugian ini tidak membuat mahasiwa akuntansi peka (sensitif) bahwa tindakan memanipulasi pembukuan perusahaan adalah tindakan yang melibatkan masalah etika. Hal ini terjadi, karena mahasiswa akuntansi menganggap tindakan memanipulasi pembukuan perusahaan merupakan tindakan yang biasa dilakukan oleh setiap perusahaan dan akuntan, demi mendapatkan citra baik dimata klien, auditor, maupun dimata masyarakat.

\section{Hipotesis 1b (H1b)}

Hasil pengujian hipotesis juga menunjukkan bahwa H1b yang menyatakan bahwa perceived societal pressure atas suatu tindakan yang merugikan, berpengaruh terhadap kemampuan seorang mahasiswa akuntansi dalam mengidentifikasi masalah etika diterima. Hasil menunjukkan bahwa perceived societal pressure berpengaruh positif terhadap sensitivitas etis mahasiswa akuntansi, yang artinya bahwa semakin tinggi perceived societal pressure maka semakin tinggi pula sensitivitas etis yang dimiliki oleh mahasiswa akuntansi.

Perceived societal pressure dalam penelitian ini menunjukkan persepsi mengenai tingkat kesepakatan sosial apakah suatu tindakan dianggap jahat (tidak etis) atau dianggap baik (etis). Hasil penelitian menunjukkan bahwa perceived societal pressure berpengaruh terhadap sensitivitas etis mahasiswa akuntansi dalam semua kasus yaitu melanggar kebijakan perusahaan, menyetujui laporan biaya yang diragukan, memanipulasi pembukuan perusahaan, dan menambah kredit yang diragukan. Hasil ini menunjukkan bahwa tindakan-tindakan pada kasus-kasus dalam penelitian dianggap merupakan tindakan yang tidak etis oleh sebagian besar orang, sehingga meningkatkan sensitivitas etis mahasiswa akuntansi. Sensitivitas etis mahasiswa akuntansi ini juga ditunjukkan ketika orang yang melakukan tindakan yang dianggap tidak etis adalah seseorang yang dekat dengan mereka (teman dekat), mahasiswa akuntansi tetap menilai bahwa tindakan yang dilakukan oleh orang terdekatnya adalah salah.

\section{Pengaruh Intensitas Moral terhadap Pertimbangan Moral Mahasiswa Akuntansi Hipotesis 2a (H2a)}

Hipotesis $2 \mathrm{~b}(\mathrm{H} 2 \mathrm{~b})$ menyatakan bahwa perceived overall harm berpengaruh terhadap kemampuan seorang mahasiswa akuntansi dalam membuat pertimbangan moral yang bertentangan dengan tindakan diterima. Hasil penelitian menunjukkan bahwa perceived overall harm berpengaruh negatif terhadap pertimbangan moral mahasiswa akuntansi. Artinya, semakin tinggi perceived overall harm, maka semakin rendah kemampuan mahasiswa akun tansi dalam membuat pertimbangan moral yang bertentangan dengan tindakan. Dengan demikian dapat dikatakan bahwa ketika suatu tindakan yang dilakukan memiliki dampak kerugian yang tinggi, mahasiswa akuntansi menilai bahwa tindakan tersebut adalah tidak etis (pertimbangan moral tinggi).

Perceived overall harm dalam penelitian ini berpengaruh negatif terhadap pertimbangan moral yang bertentangan dengan tindakan hanya pada kasus 3 yaitu memanipulasi pembukuan perusahaan. Sesuai dengan teori etika utilitiarianisme, suatu tindakan dianggap baik jika 
membawa manfaat bagi sebanyak mungkin anggota masayarakat, yang dikenal dengan istilah the greatest happiness of the greatest numbers. Artinya, tindakan dianggap baik jika tindakan tidak memiliki akibat atau konsekuensi yang buruk bagi masyarakat. Teori ini mengarahkan pada pertimbangan mengenai konsekuensi yang mungkin diterima oleh masyarakat sebelum melakukan tindakan. Seperti halnya mahasiswa akuntansi yang menilai bahwa tindakan memanipulasi pembukuan perusahaan akan menyebabkan kerugian dan risiko yang besar baik bagi perusahaan, masyarakat, klien, dan individu-individu yang bersangkutan.

Pada penelitian ini ditemukan bahwa jenis situasi yang dihadapi oleh mahasiswa akuntansi dapat mempengaruhi pertimbangan moral mahasiswa akuntansi. Mahasiswa akuntansi lebih terfokus atau tertarik dengan kasus yang memang dalam dunia nyata merupakan kasus yang dianggap fenomenal oleh masyarakat luas, dibandingkan kasus-kasus yang terjadi dalam internal perusahaan yang hanya diketahui oleh orang-orang yang bersangkutan dalam internal perusahaan. Seperti, memanipulasi pembukuan perusahaan, tindakan memanipulasi pembukuan secara nyatanya diketahui masyarakat sebagai tindakan kecurangan akuntansi, sangat tidak etis dilakukan terutama oleh akuntan. Hasil penelitian ini sejalan dengan penelitian Shinghapakdi et al., (1996), Sweeney \& Costello (2009), dan Yang \& Wu (2009), yang menunjukkan bahwa perceived overall harm berpengaruh terhadap pertimbangan moral mahasiswa akuntansi.

\section{Hipotesis 2b (H2b)}

Hipoetesis $2 \mathrm{~b}(\mathrm{H} 2 \mathrm{~b})$ menyatakan bahwa perceived societal pressure berpengaruh terhadap kemampuan seorang mahasiswa akuntansi dalam membuat pertimbangan moral yang bertentangan dengan tindakan diterima. Artinya, semakin tinggi perceived societal pressure, maka semakin tinggi pula kemampuan mahasiswa akuntansi dalam membuat pertimbangan moral yang bertentangan dengan tindakan. Hal ini menunjukkan bahwa ketika sebagaian besar orang (masyarakat) mengatakan bahwa tindakan yang dilakukan tidak etis, tidak mempengaruhi mahasiswa akuntansi dalam mambuat pertimbangan moral mereka. Mahasiswa akuntansi akan mempunyai pertimbangan moral yang bertentangan dengan apa yang kebanyakan orang katakan.

Jones (1991) berpendapat bahwa pertimbangan moral memerlukan waktu dan energi menyangkut pengumpulan fakta, mempertimbangkan prinsip-prinsip dan nilai, serta pembuatan keputusan. Mahasiswa akuntansi memiliki pertimbangan yang bertentangan dengan apa yang kebanyakan orang katakan, hal ini dikarenakan mahasiswa akuntansi memiliki pertimbanganpertimbangan tertentu atas suatu tindakan yang dilakukan. Tindakan mahasiswa akuntansi ini, didasari dengan adanya teori etika egoisme dimana tindakan yang dilakukan didasarkan pada kepentingan diri sendiri. Mahasiswa akuntansi membuat pertimbangan moral dengan memposisikan diri mereka dengan kasus dalam penelitian. Pertimbangan moral mahasiswa akuntansi dipengaruhi oleh kondisi yang dihadapi. Dapat disimpulkan bahwa perceived societal pressure berpengaruh terhadap kemampuan mahasiswa akuntansi dalam membuat pertimbangan moral yang bertentangan dengan tindakan. Pertimbangan moral yang rendah akan mengarah pada pembuatan keputusan yang salah pula. Hasil ini sejalan dengan penelitian sebelumnya (Shawver \& Shawver (2013).

\section{Pengaruh Intensitas Moral terhadap Pertimbangan Moral di Mediasi oleh Sensitivitas Etis}

Hipotesis 3 menguji ada tidaknya mediasi dari sensitivtitas etis terhadap dua dimensi intensitas moral yaitu perceived overall harm dan perceived societal pressure terhadap pertimbangan moral yang bertentangan dengan tindakan (H3a dan H3b diterima). Berdasarkan 
hasil pengujian hipotesis menunjukkan bahwa perceived overall harm berpengaruh negatif terhadap pertimbangan moral melalui sensitivitas etis. Begitu juga dengan perceived societal pressure, hasil menunjukkan bahwa perceived societal pressure berpengaruh positif terhadap pertimbangan moral melalui sensitivitas etis. Hal ini ditunjukkan dengan nilai keofisien beta pengaruh tidak langsung lebih besar dari pengaruh langsung.

Berdasarkan hasil pengujian ada tidaknya pengaruh mediasi menunjukkan adanya ketidakkonsistenan hasil penelitian untuk kasus 4 pada hipotesis sebelum mediasi hasilnya tidak signifikan, namun setelah adanya mediasi hasilnya signifikan untuk variabel perceived overall harm. Begitu juga untuk variabel perceived societal pressure menunjukkan ketidakkonsistenan hasil untuk kasus 2 pada hipotesis 1 yang signifikan, namun setelah adanya mediasi menjadi tidak signifikan. Hal ini menunjukkan bahwa variabel sensitivitas etis sebagai variabel mediasi atau perantara untuk variabel perceived overall harm dan perceived societal pressure terhadap pertimbangan moral yang bertentangan dengan tindakan memperkuat pengaruh yang sudah ada. Hasil ini sejalan dengan penelitian Shawver \& Shawver (2013), Sweeney \& Costello (2009), Shinghapakdi et al., (1996) dan Yang \& Wu (2009), yang menyatakan bahwa dua dimensi intensitas moral yaitu perceived overall harm dan perceived societal pressure berpengaruh terhadap pertimbangan moral mahasiswa akuntansi.

\section{PENUTUP}

\section{Kesimpulan, Keterbatasan, dan Saran}

Penelitian ini bertujuan untuk membuktikan apakah komponen intensitas moral berpengaruh terhadap sensitivitas etis dan pertimbangan moral mahasiswa S1 akuntansi di Universitas Bengkulu dalam proses pengambilan keputusan etis. Berdasarkan hasil analisis data dapat disimpulkan bahwa:

1. Perceived overall harm berpengaruh terhadap kemampuan sorang mahasiswa akuntansi dalam mengidentifikasi masalah etika (sensitivitas etis). Dari hasil koefisien beta yang diperoleh, menunjukkan nilai yang negatif. Hal ini berarti semakin tinggi perceived overall harm (kerugian) yang ditimbulkan atas suatu tindakan tidak etis, maka semakin rendah kemampuan seorang mahasiswa akuntansi dalam mengidentifikasi masalah etika.

2. Perceived societal pressure terhadap suatu tindakan yang merugikan, berpengaruh terhadap kemampuan mahasiswa akuntansi dalam mengidentifikasi masalah etika. Dari hasil koefisien beta yang diperoleh, mununjukkan nilai yang positif. Hal ini berarti semakin tinggi perceived societal pressure, maka semakin tinggi pula kemampuan seorang mahasiswa akuntansi dalam mengidentifikasi masalah etika.

3. Perceived overall harm berpengaruh terhadap kemampuan seorang mahasiswa akuntansi dalam membuat pertimbangan moral yang bertentangan dengan tindakan. Dari hasil koefisien beta yang diperoleh, menunjukkan nilai yang negatif. Hal ini berarti semakin tinggi perceived overall harm (kerugian) yang ditimbulkan atas suatu tindakan tidak etis, maka semakin rendah kemampuan seorang mahasiswa akuntansi dalam membuat pertimbangan moral yang bertentangan dengan tindakan.

4. Perceived societal pressure berpengaruh terhadap kemampuan seorang mahasiswa akuntansi dalam membuat pertimbangan moral yang bertentangan dengan tindakan. Dari hasil koefisien beta yang diperoleh, menunjukkan nilai yang positif. Hal ini berarti semakin tinggi perceived societal pressure, maka semakin tinggi pula kemampuan seorang mahasiswa akuntansi dalam membuat pertimbangan moral yang bertentangan dengan tindakan.

5. Perceived overall harm berpengaruh terhadap kemampuan seorang mahasiswa akuntansi dalam membuat pertimbangan moral yang bertentantang dengan tindakan melalui sensitivitas etis. 
6. Perceived societal pressure berpengaruh terhadap kemampuan seorang mahasiswa akuntansi dalam membuat pertimbangan moral yang bertentangan dengan tindakan melalui sensitivitas etis.

Secara teoritis penelitian ini mempunyai implikasi bahwa Dimensi intensitas moral dapat digunakan oleh pendidik (dosen) akuntansi khususnya sebagai alat untuk membahas kasuskasus yang berhubungan dengan masalah etika, sehingga dapat meningkatkan pemahaman mahasiswa akuntansi dalam menilai etis atau tidak suatu tindakan. Sehingga, GAP antara lulusan akuntansi dengan harapan masyarakat tidak mengalami kesenjangan yang besar.

Penelitian ini juga memiliki keterbatasan yaitu adanya ketidakkonsistenan hasil penelitian yang diperoleh ketika variabel mediasi (intervening), selain itu jumlah sampel yang digunakan masih sangat terbatas, sehingga hasilnya tidak bisa mewakili populasi yang ada diuniversitas lain. Untuk itu pada penelitian selanjutnya peneliti menyarankan agar untuk penelitian yang menguji intensitas moral dengan menggunakan kasus-kasus dilakukan dengan menggunakan metode eksperimen, sehingga hasil yang diperoleh memang benar-benar sesuai dengan yang diharapkan. Mengembangkan pernyataan yang digunakan untuk mengukur komponen intensitas moral, sehingga nantinya informasi yang diperoleh untuk masing-masing komponen akan lebih lengkap lagi. Penelitian berikutnya juga disarankan untuk meneliti bagaimana pengaruh demografi responden, agar hasil penelitian kompleks.

\section{DAFTAR PUSTAKA}

Anonim. 2016. “Kamus Besar Bahasa Indonesia Online”. Kbbi.web.id. Diakses pada tanggal 16 Oktober 2016, pukul 20:00.

Agoes, Sukrisno dan Ardana, Cenik. 2014. "Etika Bisnis Dan Profesi: Tantangan Membangun Manusia Seutuhnya". Jakarta: Salemba Empat.

Al-Fithre, Nurul Luthfie. 2015. "Pengaruh Moral Reasoning dan Etichal Sensitivity terhadap Persepsi Etis Mahasiswa Akuntansi dengan Gender sebagai Variabel Moderasi”. Skripsi. Yogyakarta: Univeritas Negeri Yogyakarta.

Arens, Alvin A., Elder, Randal J.,Beasley, Mark S \& Jusuf, Amir Abadi. 2011. “Auditing dan Pelayanan Verifikasi: Pendekatan Terpadu (Adaptasi Indonesia)". Jakarta: Salemba Empat.

Arestanti, Martana Arrazaqu., Herawati, Nurul., \& Rahmawati, Erni. 2016. "Faktor-faktor Internal Individual dalam Pembuatan Keputusan Etis: Studi pada Konsultan Pajak di Kota Surabaya". Jurnal Akuntansi dan Investasi, 17(2), 104-117.

Bertens, K. 2007. "Etika". Jakarta: PT Gramedia Pustaka Utama.

Falah, Syaikhul. 2006. "Pengaruh Budaya Etis Organisasi dan Orientasi Etika Terhadap Sensitivitas Etika". Tesis. Universitas Diponegoro.

Febriyanty. 2011. "Perkembangan Model Moral Kognitif dan Relevansinya dalam Riset-Riset Akuntansi". Jurnal Ekonomi dan Informasi Akuntansi (JENIUS), 1(1).

Ghozali, Imam. 2013. "Aplikasi Analisis Multivariate dengan Program SPSS21". Edisi keempat. Semarang: Universitas Diponegoro.

Griffin, Ricky W. 2002. "Manajemen edisi ketujuh". Jakarta: Erlangga.

Griffin, Ricky W dan Ebert, Ronald J. 2006. “ Bisnis Edisi Kedelapan”. Jakarta: Erlangga.

Himmah, Elok Faiqoh. 2013. "Persepsi Etis Mahasiswa Akuntansi Mengenai Skandal Etis Auditor dan Corporate Manager”. Jurnal Akuntansi Multiparadigma, 4 (1), 26-39.

Hunt, S.D. dan S. J. Vitell. 1986. "A General Theory Of Marketing Ethics". Journal of macromarketing, spring, 5-16.

Indriantoro, Nur \& Supomo, Bambang. 2002. “Metodologi Penelitian Bisnis Untuk Akuntansi dan Manajemen". Edisi Pertama. Yogyakarta: BPFE. 
Iswarini, Ega M., \& Mutmainah, Siti. 2012. "Pengaruh Penalaran Etis dan Faktor-Faktor Pribadi terhadap Sensitivitas Etis pada Mahasiswa Akuntansi”. Diponegoro Journal of Accounting, 1(1), 1-11.

Jones, T. 1991. "Ethical Decission Making by Individuals in Organization: An IssueContingent Model. Accademy of Management Review, 16(2), 231-248.

Juita, Beta Putri. 2011. "Sensitivitas Etis Mahasiswa Akuntansi Universitas Bengkulu”. Skripsi. Tidak Dipublikasikan.

Lestiono, Edy. 2014. "Pengaruh Locus of Control, Sifat Machiavellian dan Komitmen Profesional terhadap Perilaku Audiotor dalam Situasi Konflik Audit”. Skripsi. Universitas Islam Bandung.

Loh, C. Y., \& Wong, J. B. 2009. "Matching The Knowing What To Do And The Doing What You Know In Ethical Decision-Making”. Issue 2 Australasian Accounting Business and Finance Journal, 3.

Lubis, Arfan Ikhsan. 2010. “Akuntansi Keperilakuan". Jakarta: Salemba Empat.

Ludigdo, U., Machfoedz, M. 1999. "Persepsi Akuntansi dan Mahasiswa terhadap Etika Bisnis". Jurnal Riset Akuntansi Indonesia, 2(1), 1-19.

Natalisa, Adventina. 2015. "Level Perkembangan Moral Kognitif Akuntan dalam Pengambilan Keputusan Etis pada Saat Menghadapi Dilema Etis". Tesis. Universitas Kristen Satya Wacana.

Nikmatuniayah. 2011. "Intensitas Moral Mahasiswa Akuntansi dalam Proses Pembuatan Keputusan Moral". Prosiding Seminar Nasional Penelitian dan PKM: Sosial, Ekonomi, dan Humaniora.

Novius, Andri. 2008. "Perbedaan Persepsi Intensitas Moral Mahasiswa Akuntansi dalam Proses Pembuatan keputusan Moral'. Tesis. Semarang: Universitas Negeri Diponegoro Semarang.

Novius, Andri., \& Sabeni, Arifin. 2010. "Perbedaan Persepsi Intensitas Moral Mahasiswa Akuntansi dalam Proses Pembuatan keputusan Moral". Jurnal dan Prosiding Simposium Nasional Akuntansi, 11.

Pamela, Astriana. 2014. "Pengaruh Pemahaman Kode Etik Profesi Akuntan terhadap Perilaku Etis pada Mahasiswa Akuntansi Universitas Negeri Yogyakarta”. Skripsi. Universitas Negeri Yogyakarta.

Pradita, Feby Riska. 2013. "Perbandingan Sensitivitas Etis Account Officer Bank Umum Konvensional dan Bank Umum Syariah di Kota Surabaya”. Jurnal Ilmiah Mahasiswa FEB, 1(2). Universitas Brawijaya.

Setiawan, Agus Budi. 2011. "Pengaruh Sifat Machiavellian dan Perkembangan Moral terhadap Dysfunctional Behavior". Skripsi. Universitas Diponegoro.

Shaub, M. K., Don W. Finn dan Paul Munter. 1993. "The Effects Of Auditor's Ethical Orientation On Commitment And Ethical Sensitivitas". Behavioral Research in Accounting, 5, 145-169.

Shawer, Tara J., \& Clement, Lynn H., \& Senneti, John T. 2015. "How Does Moral Intensity Impact The Moral judgments and Whistleblowing Intentions of professional Accountants?". Research on Professional responsibility and Ethics in Accounting, 19, 27-60.

Shawver, Tara J., \& Shawver, Todd A. 2013. "Accounting Student's Ethical Sensitivity and Moral Judgments for Business Dilemmas". In Research on Professional Responsibility and Ethics in Accounting, 159-176.

Simamora, Bilson. 2005. “Ananlisis Multivariat Pemasaran”. Jakarta: PT Gramedia Pustaka Utama.

Singhapakdi, A., Vitell, S. J., \& Kraft, K L. 1996. "Moral Intensity and Ethical Decisionmaking of Marketing Professionals". Journal of Business Research, 36, 245-255. 
Sweeney, B., \& Costello, F. 2009. "Moral Intensity and Ethical Decision-making: An Empirical Examination of Undergraduate Accounting and Business Students". Accounting Education: An International Journal, 18(1), 75-97.

Thorne, L., Massey, Dawn W., \& Magnan, M. 2002. 'Institutional Context and Auditors' Moral Reasioning: A Canada-U.S. Comparison". The 2000 ISAR Conference, The 2000 Audit Midyear Meeting, and The 1999 Profesionalism and Ethics Symposium.

Umar, Husein. 2005. "Riset Pemasaran dan Perilaku Konsumen". Jakarta: Pt Gramedia Pustaka Utama dan Jakarta Business Research Center (JBRC).

Walker, L.J. 2002. "The Caracter of Moral exemplars". University of British Columbia.

Winahyuningsih, Panca., \& Harsanti, Ponny. 2013. "Analisis Determinan Sensitivitas Etika Dosen: (Studi Empiris di Universitas Muria Kudus)". Jurnal Ilmiah Inkoma, 24(1).

Yang, H., \& Wu, W. 2009. "The Effect of Moral Intensity on Ethical Decision Making in Accounting". Journal of Moral Education, 38(3), 335-351.

Yanto, Hary., Emrinaldi, N. DP., \& Anggraini, L. 2013. "Pengaruh Karakterisitik Internal dan Eksternal Auditor dalam Membuat Keputusan Audit Berbasis Etika dengan Pendekatan Moral Cognitive Menggunakan Uji Partial Least Square (PLS)". Jurnal Ekonomi, 21(4), 1-20. 